This is a self-archived version of an original article. This version may differ from the original in pagination and typographic details.

Author(s): Kauppi, Niilo; Wiesner, Claudia

Title: Exit politics, enter politicization

Year: 2018

Version: Accepted version (Final draft)

Copyright: (c) Taylor \& Francis, 2018

Rights: In Copyright

Rights url: http://rightsstatements.org/page/lnC/1.0/?language=en

Please cite the original version:

Kauppi, N., \& Wiesner, C. (2018). Exit politics, enter politicization. Journal of European Integration, 40(2), 227-233. https://doi.org/10.1080/07036337.2018.1425244 
Review article

\section{Exit Politics, Enter Politicization}

Niilo Kauppi, University of Jyväskylä and CNRS

Claudia Wiesner, University of Hamburg

3685 words

- Hoeglinger, Dominic (2015). Politicizing European Integration: Struggling with the Awakening Giant. Palgrave (Challenges to Democracy in the 21st Century).

- Hutter, Swen, Grande, Edgar and Kriesi, Hanspeter (eds.) (2016) Politicising Europe: Integration and Mass Politics. Cambridge University Press.

- Statham, Paul and Trenz, Hans-Jörg (2013) The Politicization of Europe: Contesting the Constitution in the Mass Media. Routledge (Routledge Studies on Democratising Europe).

- West European Politics 1/2016: Special Issue on 'The Differentiated Politicization of European Governance'. Editors Pieter de Wilde, Anna Leupold and Henning Schmidtke.

A growing number of recent empirical studies such as the four contributions discussed here examine the politicization of the European Union, Europe, European integration or European governance. Two general research questions mark this emerging research field. A first one is how to theorize and conceptualize the politicization of the European Union (EU) and the reasons behind it. Does politicization have to do with a decline in EU support or Euroscepticism? Does it involve an increased salience of EU affairs within national and transnational public spheres? What are politicization's repercussions on EU institutions? And How how are political parties involved? A second question is whether or not politicization is beneficial for the European integration project. Does it enhance populist, xenophobic and reactionary responses? Or does it, on the contrary, bring about a 'normalization' of EU decision making in the national arenas? 
The studies reviewed here, authored mostly by German scholars, link empirical and theoretical perspectives on politicization. They show a number of similarities in their approach to operationalising politicization and analysing it empirically. By politicization the authors refer to controversies driven by public debate, political parties and elections. The studies leave out the third research dimension that is usually mentioned in the politicization debate, the role of EU institutions (cf. de Wilde 2011). They argue that, in order to analyse politicization, researchers need to study the salience of issues, the polarization of opinions and the expansion of actors and audiences involved in debating or shaping European integration. By salience the authors understand the importance attributed to the EU and European integration, indicated by the number of newspaper articles dealing with European governance, the awareness of citizens of the EU, and the amount of public statements. Polarization refers to extreme positions, either in favour or against different aspects of European governance. Actor and audience expansion refers to the growing number of citizens and collective actors who invest time and money to follow and engage with EU governance. The setting of these processes include parliaments, public spheres and public opinion.

\section{An evolving research field}

Besides these commonalities in the approaches, the four publications set different emphases that hint at more general questions relating to the study of politicisation, regarding the concept itself and the research dimensions associated to it.

The special issue of West European Politics explores 'The Differentiated Politicization of European Governance'. The choice of words is significant, as it testifies to a crucial conceptual shift. The problématique is not European politics, or the interaction of politicization and politics, but of politicization and concepts like 'Europe', 'European governance', 'European issues', 'policy formulation in the EU', 'EU policies', 'European societies' or even 'EU affairs'. The reach of the concept is wider in Dominic Hoeglinger's Politicizing European Integration: Struggling with the Awakening Giant, which provides a sophisticated account of the politicization of European integration from the same perspective as the special issue of West European Politics. In their monograph the goal of Paul Statham and Hans-Jörg Trenz is still broader, following the title of their book. The Politicization of Europe develops an empirically grounded account of how the public sphere has been transformed and how politicization developed in response to the making of the EU's constitutional treaty. The book edited by Swen Hutter, Edgar Grande and Hanspeter Kriesi aims at an equally broad subject, Politicising Europe. These choices of concepts and of reference frames indicate a first aspect that merits further reflection in the politicisation debate: what does politicization refer 
to? What is it that is actually politicised? Is it governance, policies or 'EU affairs'? Is it 'European integration' or the EU? Or is it Europe - and hence does it concern themes and issues that refer to a context that is much broader than the EU?

The studies reviewed make it clear that the choice of research dimensions is still very much in development. In their 'Introduction: The Differentiated Politicization of European Governance', de Wilde, Leupold and Schmidtke underline that politicization takes multiple forms and that research needs to take several intermediate variables into account (p.15). The first one is member-states' influence on EU politics. According to the authors, the more a member-state perceives itself as capable of steering the EU, the more likely it is to politicize other issues than membership in the EU. The authors do not elaborate why that would be the case. The second intermediate factor they mention is the extent of member state linkages with European affairs, in particular immigration. As long as issues like migration and European governance are contested, 'the politicization of European governance is likely to survive' (p. 16). The authors mention identity and economic interests as shapers of politicization patterns. A third intermediate factor is the framing of EU governance during politicization processes.

The special issue of West European Politics includes contributions that cover different aspects of EU politicization. Grande and Hutter focus on the drivers of politicization by highlighting the mobilising power of membership conflicts (that is the degree and form of integration into the EU) and the relevance of national opportunity structures, especially referenda. Hoeglinger provides a systematic assessment of the salience of European integration in domestic election campaigns, tracking its development from the 1990s to the 2000s in six Western European countries based on media content analysis. Schmidtke analyses the causal link between growing EU authority and the politicization of EU tax governance, comparing public debates in Germany, Ireland and Switzerland between 1981 and 2011. In her chapter, Anna Leupold develops a structural approach to politicization that focuses on countries' power and varieties of capitalism, arguing for a differentiated pattern of politicization in Germany, France, Austria and Ireland before and during the euro crisis. The eurozone crisis is also the topic in Sebastian Baglioni and Achim Hurrelmann's chapter. They explore the reasons why citizen mobilization in EU-level democratic procedures has been so weak. Arndt Wonka's chapter investigates the scope, timing and divisiveness of politicization in the German Bundestag and the frames on which political parties rely in their debates. De Wilde and Lord explore the consequences of different patterns of politicization for the democratic quality of European decision-making. 
In his monograph Politicizing European Integration, Hoeglinger focuses on three key features of politicization. The first one is public debate as the central venue for political contestation in contemporary democracies (p. 7). In distinction contrast to other studies in the same vein, Hoeglinger explores the agents of politicization as well as the motives for politicization. Following de Wilde and colleagues, Hoeglinger seeks to develop an interpretation of politicization that is fusing polarization, the intensity of the public debate, and a connection of the issue to more basic political concerns. Hoeglinger disentangles the monolithic black box of European integration by distinguishing four areas: deepening, enlargement, market making and social regulation. He defines politicization as 'a process by which a particular political issue enters the field of mass politics, namely in which the audience is widened and public contestation increases' (p. 13). Like de Wilde and colleagues, Hoeglinger however forgets the second part of Schmitter's oft quoted comment on European integration, in which he speaks of 'a widening of the audience or clientele interested and active in integration' (Schmitter 1969, 166). That is European integration involves not just audiences like citizens and electors but also various political and economic clienteles.

Following the public sphere tradition that builds on the work of Jürgen Habermas, Statham and Trenz optimistically maintain that mass media led public debates and the mobilization of civil society and social movements will enhance politicization and democracy. Public debates can also grow from the national level (p. 5-6). A public sphere should allow 1) transparency on EU polity building, 2) socialization as it introduces actors to one another and 3) representation (p. 24). Statham and Trenz compare France, Germany and Britain. Their guiding thesis is that the debates around the EU's constitutional treaty represent a core example of an increasing visibility of EU decisions and of a growing contestation of the EU in the national political arenas. Pursuing a claim-making approach and a frame-analytical methodology focusing on political opportunities, they proceed to a mainly quantitative analysis of claims regarding the EU that they find in mass-mediated debate, an analysis which is complemented by findings from interviews with NGOs and actors from EU institutions. For analytical purposes, they split constitution building into three phases: 1) pre-constitution, 2) drafting (2002-Oct. 2004) and 3) ratification (Oct. 2004 - 2005; p. 25-28).

Swen Hutter, Edgar Grande, and Hanspeter Kriesi define politicization as both a key analytical concept in EU studies and a political strategy, conceptualized as the expansion of the scope of conflict in a system. Their edited book involves a considerable number of co-authors and topics. Following their goal of providing politicization with a solid empirical account, the authors study the same three dimensions that structure the other reviewed studies: 1) Issue salience, 2) actor expansion, and 3) actor polarization. They proceed from the hypotheses that authority transfers from the national to the 
EU level as well as, the rise of the radical right, real or imagined cultural shifts between the national and the EU level, and mass politics or mass protest will enhance politicization. Rather than policy issues, the conflicts have to do with constitutive issues of the EU as a polity. In contrast to the other studies reviewed, the research design is historical, cross-national, and set across political arenas. The period studied extends from the early 1970s to 2012, and the sample of countries consists of six cases: Austria, Great Britain, France, Germany, Sweden and Switzerland. The focus is on the national level, on national elections, political protest, and public debates, and the authors present an impressive number of detailed findings. The material of analysis are newspaper articles that have been subject to a relational coding. The quantitative analysis indicates different measures of salience and politicization. The authors explain in detail in the introduction and in a methodological appendix the coding as well as the calculation of the different measures.

All the authors analyse the arenas and main actors in politicization processes. Most focus on public debate and the media. They underline a key role of party politicians and public authorities in politicizing the EU/Europe via media debates. Besides this general consensus that fits with the state of the art of politicisation research, the studies differ in their analysis of the drivers of politicization.

\section{Drivers of politicization}

Regarding the factors and arenas that drive politicization, scholars agree in that referenda are seen as major opportunities for politicization. A key finding of Statham and Trenz is that the French referendum on the Constitutional treaty was the major trigger for debates in Germany and Great Britain. They also show that the German and French debates were more open and less inward-oriented than the British debate (see also Wiesner 2014). Hutter, Grande and Kriesi also conclude that referenda are an ideal opportunity for politicization because they focus the political conflict on the EU and on specific issues. Referenda provide dissenting voices better opportunities to articulate their position. Moreover, in referenda, parties have a large strategic discretion, and finally, referendum campaigns create their own momentum.

Trenz and Statham focus on the institutional perspective when they highlight the EU Commission more specifically. After the negative referenda, the European Commission's communication strategy changed from educating the public to increasing the role of civil society and NGOs. This did, howeverHowever, this did not change the dominant actor setting in politicization processes. They The authors examine the role of Brussels-based NGOs in the constitutional process. Closely linked to EU institutions and in large part funded by the European Commission, these NGOs were passive 
and did not critically discuss the constitution. Instead of contesters or actors in political mobilization, they were partners in multi-level governance, arguing for a vision of the EU as a 'stakeholder democracy'.

These findings confirm the dominance of government actors, parties, and bureaucrats in politicizing debates. Public contestation and politicization were driven by party actors, not civil society. In terms of political parties and member states, Trenz and Statham found very different shares of eurocritical claims. The most prominent eurocritics were the British Tories and the French radical left and radical right. In all member-states the leading opposition party mobilized criticism. De Wilde and Lord distinguish three actual trajectories of politicization, the remote conflict, the international conflict, and the domestic conflict. In his study, Hoeglinger demonstrates that elite attitudes to Europe are clearly structured and related to their ideological core concerns. Political and social ideology shape the way politicians emphasize European issues, and politicians are involved in a framing competition when they try to connect Europe to their political core concerns, be they economic or cultural.

A number of findings, especially in Politicising Europe, challenge the state of the art in politicization research. The most striking finding is that politicization is not a new phenomenon, but that in a historical perspective it can be described as a punctuated phenomenon, appearing in diversified patterns at different periods since the 1970s. This result decisively puts into question a core assumption of the politicization literature regarding the crucial role of the end of the "permissive consensus'. Following the seminal articles by Hooghe and Marks (2006, 2009), a key argument has been that the politicization of the EU really started only in the 1980s with a growing awareness among European citizens of European integration that enhanced political conflict and citizen dissatisfaction with European integration.

-The contributions in Politicising Europe moreover show that the assumed peaks in politicization, the debates on the Constitutional Treaty and the eurocrisis, are less important than some, like Statham and Trenz, argue. The empirical evidence draws a more nuanced picture, showing that the eurocrisis debate was a real European debate, a substantial contribution to Europeanization, and it had a strong redistributory orientation. But in sum, the eurocrisis only showed only a medium and not a high level of politicization, rather than a high level. This is in line with the main outcome of Hoeglinger's study: European integration has become politicised but it only has a limited magnitude despite the cleavage into globalization's winners and losers. 
According to Hutter, Grande and Kriesi, the reasons for moderate politicization in the eurocrisis are twofold. First, the opportunity structures spoke against politicization, as there was no referendum. [There was one in Greece in 2015, after the book manuscript was finished]. Second, the Eurozone governments followed a successful depoliticization strategy. They delegated decision-making to technocratic structures, political parties remained weak, and nationalist-identitarian frames played a minor role. Interestingly, the most europeanised debates were the least politicized, as Europeanization meant more elite participation. The trend to mass protest, the authors conclude, exists, but is overstated in the literature. The same goes for the widely shared assumption that mainly extremist parties and in particular the extreme right drive politicization. In contrast, Hutter, Grande and Kriesi distinguish three different paths to party-political politicization: 1) government-opposition conflict, 2) Eurosceptic challenger parties, and 3) conflict within mainstream.

In sum, the research reviewed provides a number of substantial findings and future research avenues. As Statham and Trenz argue, media debates indeed have the effect they expected: they cover the EU and its multi-level decision-making. There are eight factors needed for politicization in a public space via media debates: 1) Institutional opportunity structures, 2) referendum and high media attention, 3) discursive opportunities, 4) elite divisions, 5) political entrepreneurs, 6) resources, 7) justifications, and 8) a discursive struggle. But as Hutter, Grande and Kriesi demonstrate, research on politicization needs substantial revision and further elaboration. In his conclusion to the special issue of West European Politics, Michael Zürn argues that a focus on the media is too narrow and a broader view is necessary that takes into account other political levels as well as the consequences of politicization.

\section{Exit politics, enter politicisation}

Despite their merits and their impressive, and sometimes startling findings, the studies discussed deserve some critical remarks.

The first critical point concerns their analytical focus. All of them centre on public debate, media coverage, and elections and depart from the three analytical dimensions of salience, polarization, and actor participation. The studies moreover rely on mainstream media, often even on a single newspaper per member-state. Although they play a key role in politicization, the publications of political extremes and social media are not taken into account. This is particularly pertinent as 'polarization' is a core research dimension of the studies reviewed. Moreover, many of the studies rely only on quantitative analyses of the debates. This methodological choice allows for medium-N comparisons that range over long time-periods, as is most impressively demonstrated in Politicising Europe. But 
there is also a serious limitation. Counting percentages of claims or frames illustrates, but does not explain the course and the effects of public debates. Qualitative analyses of the underlying arguments and rhetorical strategies would have helped to illustrate how public discourses go about and hence explain their political dynamics. Lastly, by their methodological choices the authors discussed reproduce in their analyses top-down processes - even if they are conscious of the elite-centeredness of the debates they examine. While it is quite common in EU studies to focus on the objects of research (see Kauppi 2010) and on a set of explanatory factors that are well-established in mainstream research, this perspective leaves out dynamics and explanatory factors outside of top-down driven dynamics and actor relations. The politicization research reviewed has explored parts of a broader phenomenon of politicization the full extent of which can be discovered only after the different parts are examined together.

Second, in these studies the scholarly focus shifts from European politics to the politicization of European governance, EU issues, EU integration, Europe or some related term. Exit politics, enter politicization. Politicization has taken the place of politics in the construction of the EU as an object of political science research. What follows from this theoretical substitution is a narrow view of EU politics that obscures the crucial link between politicization and politics, that is how politicization as action disrupts, channels and challenges the more institutionalized or dominant flow of political action and established interests, be it in public or in the corridors of power. Furthermore, by defining public discussion in mainstream media as the privileged locus of politicization, this interpretation reproduces in scholarly discourse normative positions found in public discourse, positions that are either 'for' or 'against' Europe.

What is left out of this account of European politics is not only the role of political extremes, the different configurations of actors, and the details, rhetoric, and dynamics behind the processes studied. What is also missing is also the repertoire of different forms of political action (Kauppi, Palonen and Wiesner 2017) that have shaped European integration since its inception after the Second World War (see for instance Olivi 1998). Importantly, these include critical but supportive views of European integration by a variety of actors that have influenced the form European institutions have taken. These include bureaucrats like Jean Monnet and politicians like Robert Schuman. By focusing on public debate, public opinion and elections, the studies at hand de facto depoliticize most of the political actions that have guided European integration during most of its history. The key political debates have not taken place in the public sphere but in the corridors of power. The studies reviewed also minimize the fact that European politics has been -and still is- simultaneously politicized among 
certain social groups such as executive politicians and depoliticized among other social groups such as most ordinary citizens. Depoliticization strategies such as the ones used in the eurocrisis have explicitly reinforced this situation, as Hutter, Grande and Kriesi acknowledge. It is precisely this politics of depoliticization that has been a defining feature of European regional integration and that the current politicization research fails to fully capture.

All in all, in the studies discussed, the theoretical and empirical link between politics and politicization has been severed. However, as a single act or a series of acts, politicization is the condition of politics in the traditional sense. It always develops on the basis of pre-existing, established actions and institutions. Politicization as political action both precedes and follows from politics. The two depend on one another.

\section{References}

Hoeglinger, Dominic. 2015. Politicizing European Integration: Struggling with the Awakening Giant. Palgrave (Challenges to Democracy in the 21st Century).

Hooghe, Liesbet and Gary Marks. 2006. Europe's Blues: Theoretical Soul-Searching after the Rejection of the European Constitution. PS: Political Science \& Politics 39/2, 247-50.

Hooghe, Liesbet and Gary Marks. 2009. A Postfunctionalist Theory of European Integration: From Permissive Consensus to Constraining Dissensus. British Journal of Political Science 39, 1-23.

Hutter, Swen, Grande, Edgar and Kriesi, Hanspeter (eds.) (2016) Politicising Europe: Integration and Mass Politics. Cambridge University Press.

Kauppi, Niilo. 2010. The Political Ontology of European Integration. Comparative European Politics, 81, 19-36.

Kauppi, Niilo, Kari Palonen and Claudia Wiesner. 2016. The Politification and Politicization of the EU, Redescriptions 1, 72-90.

Olivi, Bino. 1998. L'Europe difficile. Histoire politique de la communaute europeenne. Paris: Gallimard

Schmitter, Philippe. 1969. Three Neo-functional Hypotheses about International Integration. International Organization 23/1, 161.

Statham, Paul and Trenz, Hans-Jörg (2013) The Politicization of Europe: Contesting the Constitution in the Mass Media. Routledge (Routledge Studies on Democratising Europe). 
West European Politics 1/2016. Special Issue on 'The Differentiated Politicization of European Governance'. Editors Pieter de Wilde, Anna Leupold and Henning Schmidtke.

Wiesner, Claudia. 2014. Demokratisierung der EU durch nationale Europadiskurse? Strukturen und Prozesse europäischer Identitätsbildung im deutsch-französischen Vergleich. Baden-Baden: Nomos.

Wilde, Pieter de. 2011. No Polity for Old Politics? A Framework for Analyzing the Politicization of European Integration. Journal of European Integration 33, 559-75. 